UDC 94(497).2)«1990/2014»

DOI https://doi.org/10.32838/2663-5984/2020/4.20

Georgieva M.D.

National Transport University

\title{
WAYS TO IMPROVE THE MECHANISM OF REGULATION OF AGRICULTURAL RELATIONS IN BULGARIA IN THE CONDITIONS OF ADAPTATION TO THE EUROPEAN REQUIREMENTS
}

This article sets out the main provisions and prospects for the development and improvement of the levers of management and regulation of the agricultural sector of the Bulgarian economy, which formed the basis for European economic integration. Priority directions of development of agrarian industry in the context of implementation of European standards are revealed. The directions of improvement of the mechanism of support of agricultural development and its activation on the European agro-food market are offered.

The analysis of the agrarian policy of Bulgaria in the historical context is conducted. The peculiarities of functioning of the mechanism of management of the agrarian sector of the Bulgarian economy have been determined and its problematic components have been identified.

In the current conditions of European integration of Bulgaria being strategically important for the state food policy, the agricultural sector of Bulgaria has been the object of reform in the process of improving the governance mechanisms, since the basic component of this economic institute was agricultural production together with social rural infrastructure. For these reasons, the development of mechanisms for public administration of agricultural sector optimization will ensure the sustainable development of a large number of Bulgarian economic sectors and, most importantly, the effective development of the social infrastructure of the village and create the foundation for the proper economic level of its inhabitants.

Thus, the implementation of a characterized and substantiated optimization mechanism of state management of the agrarian sector of Bulgaria will allow to create an effective organizational and legal basis for the development of the sector, agriculture. An important positive consequence is expected to be a significant increase in the export potential of the agricultural sector of Bulgaria, a decrease in the seasonal import dependence of the Bulgarian consumer market on agricultural products, as well as will allow to accelerate the implementation of the provisions of the Economic part of the Association Agreement between Bulgaria and the European Union.

Key words: state regulation, Bulgaria, land market, agricultural sector of economy, governance mechanisms, European Union, reforms, agriculture.

Formulation of the problem. In a market economy, the agricultural market has moved to a new quality, requiring a transition from production plans and sales of products, fixed prices to free market regulation. At the same time, experience has shown that market regulation in its pure form does not harmonize the interests of producers and buyers of agricultural products, so there is a need to supplement market relations with state regulation of the agricultural market.

However, as domestic practice has shown, government regulation of the market is not always effective due to limited resources to influence the market; lack of awareness about the activities of agricultural producers, the state of intra-regional and inter-regional agricultural markets, balance sheets of agricultural products, export-import activities; limited control over the private agricultural sector, etc. Therefore, the main task of state regulation of the agricultural sector should be a focused policy of priority areas for the development of the agricultural market. It is these circumstances that necessitated the justification of state regulation of the agricultural market.

The agricultural sector of the economy has historically been one of the main branches of the Bulgarian economy. He has always been closely associated with resources, business culture, traditions, natural conditions, skilled professionals and technical capabilities.

In the early 1990s, the European Union regarded Bulgaria as the "vegetable basket of Europe". But the Bulgarian agrarian sector was not ready to comply with European norms and standards of produced agricultural products, as it stood on the threshold of the beginning of the reform of agrarian relations. 
Analysis of recent research and publications. The national historical science has not paid enough attention to the development of the agrarian sector of the Bulgarian economy during the 1990s.

Various aspects of the tendency of development of agricultural production in Bulgaria are covered in the works of Bulgarian scientists, in particular, R. Popov [6], B. Stoimenov [8], N. Velchev [2], Y. Doluda [3].

Setting objectives. The purpose of the article is to analyze the main trends of the current stage of development of the agrarian sector of the Bulgarian economy and to substantiate a set of measures to consolidate the positive dynamics of the development of the industry.

Outline of the main research material. After the collapse of the socialism system in Bulgaria in 1989-1990s, the process of agrarian reform began. Key areas of reform - from the line for the revival of cooperative agricultural farms on the basis of full voluntariness and economic independence with the constant restoration of land ownership of peasants to a course on the mandatory elimination of cooperatives and accelerated privatization of land, property of nonagricultural industries AIC with the state support of market restructuring [7, p. 4].

The unified and centralized system of agriculture of state socialism naturally gave way to a new model of development based on market-type links between economic units. In 1990 the following changes were made to the agrarian policy of the country: complete elimination of state orders in agriculture, establishment of free market prices for agricultural products, which amounted to about one third of its gross volume, etc., that is, some decentralization was allowed while maintaining the focus on large collective agricultural enterprises. farms.

The peculiarity of Bulgarian agriculture to the reform was that the land functioned economically as state property and was not legally nationalized. The divestment in agriculture began with the adoption in March 1991 of the Law on Ownership and Use of Agricultural Land [4]. According to the law, the owners of agricultural lands could be the state, the community, legal entities and individuals $[9$, p. 16]. The rights of former landowners and their heirs to the land were restored. The activities of cooperative agricultural farms and previously established all types of agricultural cooperatives and agricultural companies were discontinued.

In the 1990s, Bulgaria began to make the transition to becoming a private peasant economy. With the adoption of the last, final version of the Land Law (1992), large-scale privatization began in the country's agriculture [8, p. 13]. The rights of agricultural cooperatives operating in Bulgaria until 1944 were restored and their property confiscated. By 1995 , the number of private farms in the country was $1,777,000$, more than $86 \%$ from 1 ha of land, $12.3 \%$ to $5 \mathrm{ha}$, and more than $5 \mathrm{ha}-1 \%[8, \mathrm{p} .4-15]$.

One of the fundamental moments of the economic reform in the Bulgarian agriculture was the refusal of the state from administrative interference in the activities of agricultural producers. All manufacturers began to freely decide on the number of manufactured and sold products without any restrictions, which, according to some experts, was a hasty decision due to the lack of real conditions for competition and the choice of contractors. The Bulgarian government has taken control of prices for goods that provided $50 \%$ of gross agricultural output $[5$, p. $32-33]$ and protected from adverse effects. Immediately after the decision to liquidate cooperative agricultural farms was reached, the problem arose of the refusal of commercial banks to provide loans to organizations subject to liquidation. There was a real threat of the complete failure of the 1992 spring sowing campaign, as agricultural cooperatives lacked their own funds.

The destruction of agrarian organizational structures has led to a catastrophic decline in agricultural production, producers' incomes, unemployment, and poverty. In the period 1991-1994, agricultural production decreased by $35 \%$. The main manifestation of this was the sharp decline in production. Thus, in 1990 compared to 1989 , this decline amounted to $6 \%$ ( $7.4 \%$ in crop production, $4.6 \%$ - in animal husbandry), in 1991 compared to 1990, agricultural production decreased by $6.4 \%$ (including in livestock by $15.7 \%$ ), in 1992 - by $12 \%$ [1, p. 11].

By 1997, the output of agricultural products had decreased and was 40\% less than $1990[6$,$] .$ Crop production continued to prevail over livestock production, with the exception of the grain crisis in 1993 and 1996, which was associated with adverse climatic conditions. The sharp decrease in the volume of livestock production in the transition period showed that in a centralized economy, livestock production developed under artificial, "greenhouse" conditions.

The collapse of huge livestock complexes and the change in the ratio of prices for livestock and plant products greatly reduced the ability to care for animals.

In 1997-1998, agricultural production accounted for $17 \%$ of the country's GDP, accounting for $21 \%$ of the economically active population. Analysis of statistical information for the years 1987-1996 showed that the volume of agricultural 
production decreased to $72.2 \%$ (including crop production $-84.5 \%$, animal husbandry $-60.6 \%$ ). In 1997, the total agricultural production was about $60 \%$ of the annual average in 1980-1990s. The area under cereals was steadily declining [3, p. 76].

In 1997, under relatively favorable climatic conditions, grain production accounted for $70 \%$ of the average harvest of the 1980s, and industrial crops - 55\%. A significant decline was observed in animal husbandry: the number of cows decreased by $60 \%$, pigs - by $55 \%$, poultry - by $40 \%$, respectively production of meat, milk, wool decreased (by about $50 \%$ ). In $1996,95 \%$ of agricultural output came from the private sector, including agricultural cooperatives (in the period 1991-1997, 62\% of land was returned to its former owners) [2, p. 7].

The decline in production was also caused by the collapse of the USSR, as Bulgaria was economically oriented toward the Soviet Union for many years, and Russia in the 1990s drastically reduced purchases in Southeastern Europe, including Bulgaria.

The sharp decline in agricultural production has had a strong destabilizing impact on the economy as a whole, becoming one of the main factors behind the decline in real incomes of the population, increasing social tensions and instability of the political situation in the country. In 10 years, GDP per capita has more than halved.

In the first five years of the reform (1991-1995), the former owners and their heirs received almost half of the land given for restitution [9, p. 18]. In 1995 , about $3 / 4$ of all agricultural production was produced in the private sector. However, the growth of private sector production did not offset the fall in overall output during the agrarian reform. In 1995, its volume was $14.6 \%$ below the level of 1989 and $8.4 \%$ less than in 1990 [1, p. 11].

The crisis of agriculture most Bulgarian researchers reasonably associate with the negative aspects of land reform. The initial basis for restitution of land ownership was adopted in 1946, with the characteristic of it small, scattered land ownership, without due consideration of changes in the following years. The chosen alternative of natural restitution not only meant a return to the smallholder structure of land tenure, but also enhanced it.

At the same time, due to the long demographic changes among the employed in agriculture, the contingent of the active age sharply decreased, a considerable part of the youth left the Bulgarian village. More than half of future landowners have become urban dwellers, and about $30 \%$ of peasants are elderly. The fragmented land ownership, irrationally located on the subjects, did not create the preconditions for the development of modern automated and mechanized production. Agrarian farms (5 to 10 hectares or more) were relatively large in the country, occupying more than $2 / 5$ of the private land, but as a rule they were given temporary use.

By the mid-1990s it became clear that a solution to the current situation could be sought in two main ways. First, in the development of agricultural cooperatives, but not through the resuscitation of the collective farm system and the reproduction of old TKZG, and through the formation of true agrarian cooperatives as associations of real private landowners. Secondly, in the development of farms on the basis of accelerating restitution and at the same time building a full-fledged land market [6, p. 9].

By mid-1998, most of the country's agricultural land had been restored. The stabilization of land ownership relations has largely contributed to the overall stabilization of agriculture and the growth of agricultural production in Bulgaria.

Conclusions. The analysis of the development of market relations, agrarian sphere of Bulgaria in the 1990's allows us to draw the following conclusions:

1. During the period of transition of the country's economy to market relations, significant changes occurred in its agrarian sphere - reforming the TKZG, restoring the rights of the former owners and their heirs to the land. The land transfer to new owners was limited and for a fee that was differentiated according to its category.

2. The realization of land ownership rights was envisaged in accordance with the Law on Ownership and Use of Agricultural Land in the following options: organization of a private peasant farm; transfer of land to a community or state fund for a fee; leasing; preservation of land in newly established cooperatives and receipt of rent in the amount stipulated by the founding agreement; providing land on certain terms as a unit in a cooperative.

3. The property of disbanded TCZGs and other types of cooperatives formed prior to the adoption of the Law on Ownership and Use of Agricultural Land shall be subject to division between their members.

4. Former forms of work organization in agriculture were eliminated, private peasant farms and new cooperatives were created.

5. The state virtually abandoned administrative interference with the activities of producers and provided priority to economic levers.

6. Farmers in 1992 received tax benefits - for 5 years they were not taxed on gross income, and individual categories of citizens for a longer period. 
The practice of agrarian reform of Bulgaria in the 1990s shows:

1. For successful implementation of agrarian reforms, it is necessary to take into account the specific features of both the agrarian sector of the country and the transition to market conditions.

2. Effective state regulation of economic processes occurring in the agrarian sector must be maintained, especially in a difficult transition period, which, however, should be radically different from the previous methods inherent in the administrative and command system of management of the agrarian sector of the Bulgarian economy.

3. It was unacceptable to hastily force the destruction of all forms of former organizational structures before the active process of forming new ones began.

The analysis of the Bulgarian experience in the organization of the agrarian market and the management of its operation made it possible to identify the following main regularities in public administration: 1) regulation of land use. This trend was aimed at minimizing the economic burden on agricultural land in the process of obtaining the maximum economic effect from their use in the process of agricultural production; 2) balanced control over pricing. This trend is represented by an effective pricing policy built on the protectionism of production of its own producers, which is combined with a customs tariff policy on imports of agricultural products; $3)$ economic and legal incentives for investment. This trend envisaged the application of tax incentive methods for agrarians, which helped to increase the profitability of agricultural enterprises, the creation of tax holidays and the use of other mechanisms to manage the process of attracting investment resources in enterprises of the agricultural sector.

However, the study of integration processes as a component of the competitive development of the Bulgarian agricultural market in the conditions of European standards showed the positive impact of the introduction of European standards in the mechanisms of public administration of the agrarian sector of Bulgaria. It was also evident that the introduction of quality standards in agricultural production forced the national producer to introduce innovative technological processes into production, which in turn increased food security and laid the preconditions for the competitiveness of Bulgarian agricultural products. At the same time, the study of the components of the public sector governance mechanism in the EU and Bulgaria has highlighted the following characteristic components of this mechanism in the European Union: 1) financial impact on the development of the sector (intervention, financing, subsidies, etc.) in the medium and longterm development programs; 2) standardization of conditions regarding product quality and food security; 3) implementation of priorities for socioeconomic development of rural areas.

At the same time, the current practice of functioning of the mechanism of state management of the agricultural sector in Bulgaria is presented as a system of state and self-governing bodies, which implemented a regulatory policy rather than a policy of financial and organizational support. This was the reason for the lagging behind of the economic development of the agricultural sector of Bulgaria and the low quality of agricultural produce. The general direction of reconstruction of the components of the mechanism of state management of the agrarian sector of Ukraine determines the reorientation of public administration from a regulatory to a stimulating and securing function, which should synchronize the main directions of agrarian policy of Ukraine and the EU in exportimport relations, as well as stimulate the technical and industrial reorganization of Ukraine.

In this context, it is important to establish the importance of the interaction of market selfregulation mechanisms and public administration in the agricultural sector at the national, regional and sectoral levels of agricultural sector management in order to meet domestic demand and maintain competitiveness in the international market for agricultural products. We consider the areas of effective use of interaction features to predict the contradictions between government mechanisms and market trends, which creates a platform for determining the scope of implementation of EU norms and standards, taking into account domestic features of agricultural development.

\section{References:}

1. Бяла книга за положението на страната в началото на мандата на 37-то Народно събрание. Дума. София, 1995. 22 марта. С. 5-30.

2. Вълчев Н. Възстановяването на зърнопроизводството - първа и решаваща мярка на извеждане на земеделието от кризата. Икономика и управление на селското стопанство. София, 1997. № 2. С. 4-26.

3. Долуда Ю. Болгария. Аграрные реформы в зарубежных постсоциалистических странах: Первый этап. Москва : РАН, 1993. 119 с. 
4. Закон за собственността и ползуваннето на селскостопанските земи. Земя. София, 1990. 22 ноември. С. 1-70.

5. Людникова Г. Аграрная реформа и развитие рыночных отношений в республике Болгария. Международный селькохозяйственный журнал. 1993. № 3. С. 21-52.

6. Попов Р. Среднесрочни аспекти на аграрната политика в България. Икономика и управление на селското стопанство. 1998. № 7. С. 3-37.

7. Симова А. Подготовка на българското селско стопанство за присъединяването на страната към ЕС. Икономическа мисъл. 1998. № 5. С. 4-46.

8. Стоименов Б.К. Приватизация в сельском хозяйстве. Селскостопанска наука. София, 1992. № 4-6. C. 3.

9. Шабунина В. Некоторые аспекты реформирования аграрной сферы в Болгарии. Международный селькохозяйственный журнал. 1997. № 3. С. 17.

\section{Георгієва М.Д. ШЛЯХИ ВДОСКОНАЛЕННЯ МЕХАНІЗМУ РЕГУЛЮВАННЯ СІЛЬСЬКОГОСПОДАРСЬКИХ ВІДНОСИН БОЛГАРІЇ ЗА УМОВ ПРИСДНАННЯ ДО ЄВРОПЕЙСЬКИХ ВИМОГ}

У статті викладені основні положення та перспективи розвитку й удосконалення важелів управління та регулювання аграрного сектора економіки Болгарії, які лягли в основу європейськоі економічної інтеграчії. Розкрито пріоритетні напрями розвитку аграрної галузі в контексті впровадження європейських стандартів. Запропоновано напрями вдосконалення механізму підтримки розвитку сільського господарства та його активізаиії на європейському ринку агропродовольчих товарів.

Проводиться аналіз аграрної політики Болгарії в історичному контексті. Визначено особливості функціонування механізму управління аграрним сектором економіки Болгарії та визначено ї проблемні компоненти.

За сучасних умов євроінтеграчії сільськогосподарський сектор Болгарії став об'єктом реформи у процесі вдосконалення механізмів управління, оскільки основним компонентом иього економічного інституту було спільне виробництво сільського господарства із соціальною сільською інфраструктурою. 3 ичих причин розробка механізмів держсавного управління оптимізацією аграрного сектору забезпечить стійкий розвиток великої кількості економічних секторів Болгарї та, що найголовніше, ефективний розвиток соціальної інфраструктури села та створить фундамент для належного економічний рівень його мешканців.

Таким чином, реалізація характерного та обтрунтованого механізму оптимізаціїдержавного управління аграрним сектором Болгарії дозволить створити ефективну організаиійно-правову базу для розвитку галузі, сільського господарства. Очікується, ще важливим позитивним наслідком буде значне збільшення експортного потенціалу аграрного сектору Болгарії, зменшення сезонної імпортної залежності споживчого ринку Болгарії від сільськогосподарської продукиії, а також дозволить прискорити виконання положень економічної частини Угоди про асоиіацію між Болгарією та Європейським Союзом.

Ключові слова: державне регулювання, Болгарія, ринок землі, аграрний сектор економіки, механізми управління, Свропейський Союз, реформи, сільське господарство. 